\title{
中国矿产资源基地划定指标体系构建与应用 一以铁矿为例
}

\author{
张玉韩 ${ }^{1,2}$, 吴尚昆 ${ }^{2}$, 张寿庭 ${ }^{1}$, 王成福 ${ }^{1}$, 赵 $^{{ }^{1}}$ \\ (1. 中国地质大学 (北京)地球科学与资源学院, 北京 $100083 ; 2$. 中国自然资源经济研究院, 北京 101149)
}

\begin{abstract}
摘要: 矿产资源基地是优化中国矿产资源勘查开发布局、保障国内资源有效供应的战略核心 区域。在分析基地布局影响因素的基础上, 从资源基础、开发条件、市场需求和国家战略等方 面构建了矿产资源基地划定指标体系。其中资源基础包括预测资源量、查明资源储量和设计 开采规模, 开发条件包括缺水程度和交通优势度, 市场需求包括后续冶炼加工企业布局与产 值, 国家战略主要体现为区域协调发展战略对矿产资源基地布局的要求。在此基础上, 以铁矿 为例开展了实证研究, 采用聚类分析、核密度估计等方法对各单项指标进行了分析评价, 在全 国识别了辽宁鞍山一本溪等 12 个铁矿资源基地。研究结果可以为 “十四五”时期中国矿产资源 基地调整优化提供参考,对其他矿产资源空间政策区的划定具有一定借鉴意义。
\end{abstract}

关键词: 矿产资源基地; 指标体系; 铁矿; 核密度估计

矿产资源是国民经济和社会发展不可或缺的基本原材料 ${ }^{[1]}$ ，也是一个国家综合国力的 重要组成部分。近年来, 中国资源需求增速虽然放缓, 但需求总量仍维持高位, 供需矛 盾日益突出, 进口大幅增加 ${ }^{[2]}$ 。未来十年, 中国大力发展战略性新兴产业和建设全球制造 业强国两大战略对矿产资源的需求仍然较大 ${ }^{[3]}$ 。资源安全已成为保障实现第二个百年目标 和中华民族伟大复兴的重大战略任务 ${ }^{[4]}$ 。一国或地区维护本国矿产资源安全的首要手段是 保证国内资源的充分生产和有效利用，以从内部解决资源供需问题 ${ }^{[5]}$ 。另一方面，随着当 前中国经济发展方式由高速增长向高质量发展的转变 ${ }^{[6]}$, 矿业在高质量发展中的地位和作 用越来越突出 ${ }^{[7]}$ 。党的 “十九大” 报告提出推进 “资源全面节约和循环利用”, 形成 “绿 色发展方式和生活方式” ${ }^{[8]}$ ，对矿产资源集约规模化开发利用提出了更高要求。综合来 看，当前中国矿产资源面临着保障资源有效供给与实现高质量发展的双重压力。建设大 型矿产资源基地，在空间上形成一批重要矿产资源供应集中区，有利于推进资源规模开 采与有效利用，并增强矿产资源的有效供给能力 ${ }^{[9]}$ 。

划定空间政策区并开展空间管制是自然资源管理、生态环境保护和空间规划等部门 行使资源开发与保护、环境保护以及优化城市发展格局等职责的有效手段 ${ }^{[10]}$ 。如：环境保 护方面，通过划定自然保护区并制定严格的管理政策，是许多国家保护生态环境不受破 坏的主要措施之一 ${ }^{[11,12]}$; 生物多样性保护方面, 重要区域的识别是制定和实施保护计划的 首要步骤 ${ }^{[13]}$, 为使有限的投人达到最佳的保护效果 ${ }^{[14]}$, 许多国家开展了生物多样性优先保

收稿日期：2020-03-13；修订日期：2020-07-13

基金项目：自然资源部地质调查项目（DD20190827); 自然资源部部门预算项目（121102000000180008）

作者简介: 张玉韩 (1990- ), 女, 河南鹤壁人, 博士研究生, 助理研究员, 主要从事国土资源产业经济与管理研究。 E-mail: zhangyuhanwinter@sina.com

通讯作者: 吴尚昆 (1976- ), 男, 河北滦县人, 博士, 研究员, 主要从事矿产资源规划与绿色矿业发展研究。

E-mail: skwu@canre.org.cn 
护区域划定研究 ${ }^{[15]}$; 空间规划方面, 德国、英国、日本等国家均较为重视以问题为导向的 政策区域划分 ${ }^{[16,17]}$; 矿产资源管理方面，英国、美国、俄罗斯、加拿大、澳大利亚等矿产 资源大国往往重视矿产资源开发的空间管治作用，这种空间管治在一定程度上体现了分 区管理思想 ${ }^{[18-20]}$ ，如英格兰划定的矿产资源保护区（Mineral Safeguarding Areas） ${ }^{[21]}$ ，英国

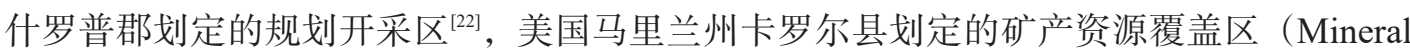
Resource Overlay Zones） ${ }^{[23]}$ ，澳大利亚昆士兰和西澳大利亚划定的关键资源区（Key Resource Areas）与资源优先区（Priority Resource Locations） ${ }^{[24]}$ 等。

矿产资源基地是中国矿产资源分区管理的重要政策工具，其实质是矿产资源管理制度 的载体。Amiri 等 ${ }^{[25]}$ 通过研究表明, 制度质量的提高能够促进一个国家更有效地利用其丰 富的自然资源，以实现更高的经济增长。矿产资源基地是从区划角度将维持国内矿产资源 保障底线所需的 “量” 转化到空间上，找到矿产资源有效供给对应的空间需求。自《全国 矿产资源规划（2016-2020年）》提出建设103个基地以来，矿产资源基地已成为目前中 国最重要的矿产资源空间政策区之一。中国的 “十四五” 矿产资源规划已经启动，矿产资 源基地作为落实战略性矿产有效供给、推进矿业高质量发展的重要抓手之一，其地位将更 加重要, 对基地进行科学划定是开展后续资源管理、促进政策有效落地的基础前提。

国内学者针对大型煤炭基地、矿产资源后备基地、储备基地以及勘查开发基地等开 展了一系列研究 ${ }^{[2-31]}$, 但总体思路仍主要以矿产资源本身的空间分布特征来识别矿产资源 基地 ${ }^{[22-34]}$, 缺乏一定综合性, 无法适应新时代下矿产资源基地管理需求 ${ }^{\left[{ }^{[0]}\right.}$ 。虽然部分学者 已提出应考虑矿山开发条件和生态环境等因素来划定矿产资源基地 ${ }^{[35]}$, 但在实证研究中 未进行应用。基于此，本文拟在分析矿产资源基地布局影响因素的基础上，从综合角度 构建矿产资源基地划定指标体系，并以铁矿为例开展基地划定实证研究，以期为 “十四 五” 时期矿产资源基地调整优化与后续管理提供支撑。

\section{1 研究方法与数据来源}

\section{1 矿产资源基地布局影响因素分析}

首先，作为国内资源有效供应的战略核心区域，矿产资源基地内的远景资源潜力、 资源储量, 或矿产资源生产能力必须在全国占据重要地位, 是国家重要的矿产资源潜 力、储量或产能富集区。不同于资本、劳动等要素, 矿产资源是一种特殊的生产要素, 它赋存在哪些地区就必须在哪些地区进行开发, 一些矿种还需要就地进行加工, 因此, 区域矿产资源禀赋条件是影响矿产资源基地布局的最基础要素。

其次, 从矿业的整个产业链来看, 矿产资源基地覆盖的领域主要集中在产业链的前 端, 包括矿产资源的勘查、开发、储备保护等，但资源安全的内涵还涉及需求方面 ${ }^{[3]}$ 。 矿产资源基地作为中国资源安全保障的战略核心区域，其布局除了要考虑矿产资源禀赋 条件外，还应考虑与下游冶炼加工企业需求的衔接，力争通过基地建设促进上下游产业 一体化发展。

此外，除以储备为目的的基地外，无论是以勘查为导向还是以开发为导向的矿产资 源基地, 其建设的最终目的均是为了能够实现资源的规模化集约化开发。因此, 影响矿 产资源开发的外部条件也是基地布局的重要影响因素。这些外部条件包括水资源、能源 等支撑矿产资源开采的要素，生态环境保护等制约矿产资源勘查开发的要素，基础设施 
等影响矿产资源运输与贸易的要素，以及国家和区域发展战略等要素 ${ }^{[37,38]}$ 。

综合以上分析认为，矿产资源基地布局主要受到资源基础、开发条件、生态环境、 市场需求以及国家战略的影响。具体来看，资源基础包括资源潜力、资源储量以及产能 等三个方面，开发条件主要包括基础设施、水资源、能源等支撑矿产资源开发与贸易的 要素, 市场需求主要表现为矿产资源的最直接需求对象一一冶炼加工企业的需求。此 外，作为国家的空间政策区之一，矿产资源基地建设还应贯彻落实国家重大发展战略， 其中最直接相关的是区域协调发展战略。生态环境对矿产资源基地的影响主要体现在后 续发展导向上，决定了是以储备保护为导向还是以勘查开发为导向。

\section{2 矿产资源基地划定指标体系构建}

根据矿产资源基地布局影响因素分析结果，遵循科学性、可比性、易获性、可操作 性等原则，本文选择资源基础、开发条件、市场需求和国家战略为准则层指标，各准则 层由若干项具体指标来反映。其中资源基础指标参考侯华丽等 ${ }^{[39]}$ 关于矿产资源丰度的研 究结果, 采用查明资源储量与设计开采规模来分别反映矿产资源的储量与产能高低, 并 增加反映矿产资源潜力的预测资源量指标; 开发条件准则包括交通优势度和缺水程度两 项指标，之所以未考虑反映能源支撑方面的指标，是由于已有研究中常用发电量指标来 反映地区能源供给条件 ${ }^{[40]}$, 而发电量指标在县级行政区小尺度上的数据难以获取, 大尺 度数据对矿产资源基地划定的参考意义不大; 交通优势度借鉴了金凤君等 ${ }^{\left[{ }^{[4]}\right.}$ 关于交通条 件优劣的评价指标; 市场需求包括冶炼与压延加工业布局、冶炼与压延加工业产值两项 指标, 国家战略主要是区域协调发展战略。具体如表 1 所示。

\section{表 1 矿产资源基地识别指标体系}

Table 1 Identification index system of mineral resources bases

\begin{tabular}{clll}
\hline 目标层 & 准则层 & 指标层 & 指标功能 \\
\hline 矿产资源 & 资源基础 & 预测资源量 & 反映矿产资源潜力 \\
基地布局 & & 反映矿产资源储量 \\
& & 查明资源储量 & 反映矿产资源产能 \\
& 设计开采规模 & 反映交通基础设施发展水平 \\
& 开发条件 & 交通优势度 & 反映支撑矿产开发的水资源供给条件 \\
& 缺水程度 & 反映产业链下游市场分布 \\
& 市场需求 & 冶炼与压延加工业布局 & 反映产业链下游市场需求程度 \\
& & 冶炼与压延加工业产值 & 反映国家发展战略对矿产资源勘查开发的需求 \\
\hline
\end{tabular}

\section{3 研究方法}

铁矿资源基地识别采用定性与定量相结合的方法。首先，采用聚类分析方法对铁矿 三级预测区预测资源量、矿区查明资源储量以及采矿权设计开采规模进行分析，初步识 别铁矿资源潜力富集区、储量富集区和产能富集区; 其次，结合开发条件、市场需求评 价结果, 并考虑区域协调发展战略进行综合判断, 确定铁矿资源基地名单。各指标计算 方法如下：预测资源量采用ArcGIS 中的自然断点法（Natural Breaks）进行聚类分析，矿 区查明资源储量和采矿权设计开采规模采用核密度估计方法进行评价，开发条件指标采 用已有研究成果。

核密度估计（Kernel Density Estimation）由 Rosenblat ${ }^{[42]}$ 和 $\operatorname{Parzen}^{[43]}$ 提出，是在概率论 
中用来估计未知的密度函数, 它基于已知数据, 采用无参数估计法对未知概率密度函数 进行估计，使得估计得到的概率密度函数与实际的概率密度间的均方积分误差最小。 核密度估计法的关键是核函数的选取以及窗口宽度，即带宽的确定。计算公式如下 ${ }^{[44]}$ :

$$
\hat{f}(x)=\frac{1}{n h} \sum_{i=1}^{n} K(x)
$$

式中： $h$ 为带宽; $K(x)$ 为核函数; $n$ 为数据条数（条）。基于 ArcGIS 平台进行运算，其 中默认核函数为 $\operatorname{Silverman}^{[45]}$ 提出的二次核函数 (Epanechnikov), 公式为:

$$
K(x)=\left\{\begin{array}{l}
\frac{3}{4}\left(1-x^{2}\right), x \in[-1,1] \\
0, \text { o th erwise }
\end{array}\right.
$$

默认带宽 $h$ 的计算公式为 ${ }^{[46]}$ :

$$
h=0.9 \times \min \left(S D, \sqrt{\frac{1}{\ln 2}} \times D_{m}\right) \times \sum_{i=1}^{n} x_{i}^{-0.2}
$$

式中: $S D$ 为标准距离; $D_{m}$ 为中值距离。

\section{4 数据来源}

预测资源量指标以三级预测区作为评价单元，涉及铁矿三级预测区范围、2000 m 以 浅预测资源量和 $500 \mathrm{~m}$ 以浅预测资源量等数据，其中预测区范围采用阴江宁等 ${ }^{[47]}$ 关于中 国铁矿资源潜力分析的研究结果，预测资源量数据来源于中国地质调查局资源评价部、 中国地质科学院矿产资源研究所《资源潜力评价与选区研究系列报告》成果，为 2013 年 数据。铁矿矿区查明资源储量、采矿权设计开采规模数据均来源于自然资源部信息中 心，为 2017 年数据。黑色金属治炼及压延加工企业坐标数据根据其注册地址，在地图上 数字化生成，数据截至 2019 年 10 月。交通优势度指标参考金凤君等 ${ }^{[4]}$ 关于中国县级行政 单元交通优势度的测算结果。缺水程度指标采用中国水利部关于全国缺水程度评价区的 成果，全国共分为 “基本不缺水” “轻微缺水” “中度缺水” “较严重缺水” 和 “严重缺 水” 等五种类型区。研究范围为中国大陆, 不包括港澳台。

\section{2 结果分析}

本文选择铁矿作为实证研究对象，主要考虑以下两点：第一，铁矿在中国的战略性 地位比较高, 是中国的大宗矿产 ${ }^{[48]}$ 和重要矿产 ${ }^{[49]}$, 也是 24 个战略性矿产之一，以铁矿为 主要原料的钢铁工业是中国工业的粮食; 第二，中国铁矿资源对外依存度较高，2018年 已超过了 $70 \%{ }^{[50]}$, 保障国内资源安全底线任务重, 建设矿产资源基地的需求更为迫切。

\section{1 铁矿资源基础评价}

\subsection{1 预测资源量评价}

以 $2000 \mathrm{~m}$ 以浅预测资源量指标评价结果来识别铁矿资源潜力富集区，并参考 $500 \mathrm{~m}$ 以浅预测资源量指标进行修正。中国铁矿 $2000 \mathrm{~m}$ 以浅预测资源量分级结果如图 1 所示, 其中前两级, 即 $2000 \mathrm{~m}$ 以浅预测资源量大于 40 亿 $\mathrm{t}$ 的三级预测区共有 10 个, 分别为辽宁 本溪市弓长岭、辽宁鞍山市灵山一齐大山一千山、四川攀枝花、河北遵化市石人沟、河 北唐山市司家营、四川攀枝花市白马、安徽霍邱县石店镇一河口镇、四川铁矿山一大顶 山、安徽马鞍山市徐家一中刘（马芜地区）、云南惠民等。上述 10 个铁矿三级预测区 中, 四川铁矿山一大顶山预测区虽 $2000 \mathrm{~m}$ 以浅预测资源量较大，但 $500 \mathrm{~m}$ 以浅铁矿预测 
资源量较少，仅排到了全国第 126 位。综合判断, 确定辽宁本溪市弓 长岭等 9 个三级预测区为铁矿潜力富 集区。

\subsection{2 矿区查明资源储量分析}

以铁矿矿区查明资源储量核密 度分析结果来识别铁矿储量富集 区。分析结果如图 2 所示, 颜色越深 表示查明资源储量高值区集聚越明 显。从图中可以看出, 一级核主要 有 9 个, 分布在辽宁鞍山一本溪地 区、河北东部、山西忻州一吕梁地 区、山东中部和西部地区、安徽霍 邱地区、安徽庐江一马鞍山地区、 湖北西南部、四川攀枝花一西昌地 区以及云南澜沧地区，一级核面积 最大的为辽宁鞍山一本溪地区, 其 次为四川攀枝花一西昌和河北东 部。总体来看, 一级核主要分布在 胡焕庸线东南部, 西北部有几处二 级核, 其中面积较大的包括甘肃张 掖地区、新疆天山和西昆仑地区等。

\subsection{3 采矿权设计开采规模分析}

以铁矿采矿权设计开采规模核 密度分析结果来识别铁矿产能富集 区, 分析结果如图 3 所示, 颜色越深 表示采矿权设计开采规模高值区集 聚越明显。从图中可以看出, 一级 和二级核有 8 个, 分布在辽宁鞍山一 本溪地区、河北东部、山西忻州一 吕梁地区、山东西部、内蒙古包头 地区、安徽霍邱地区、安徽庐江一

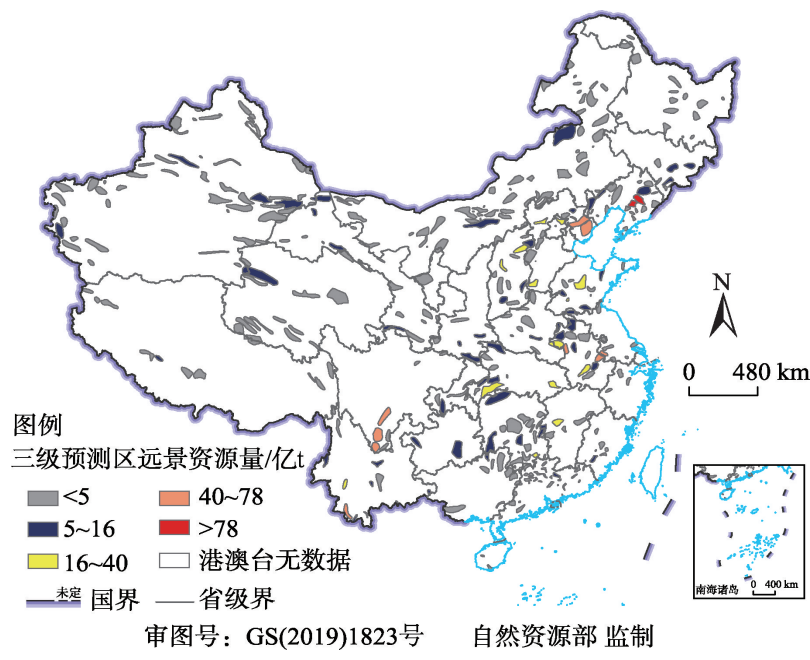

注: 本图基于自然资源部标准地图服务系统下载的标准地图 制作，底图无修改，下同。

图 1 中国铁矿三级预测区 $2000 \mathrm{~m}$ 以浅预测资源量 ${ }^{[4]}$

Fig. 1 The predicted resources at a depth of $2000 \mathrm{~m}$ in the third-grade prediction area of iron ore in China

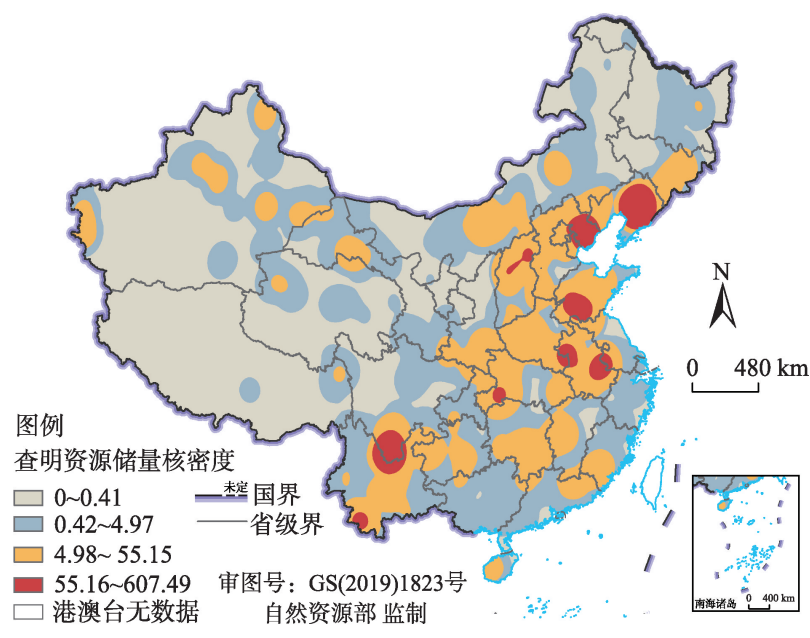

图 2 中国铁矿区查明资源储量核密度

Fig. 2 Kernel density distribution of identified resource reserves of iron ore districts in China

马鞍山地区、四川攀枝花一西昌地区，其中一级核仅在辽宁鞍山一本溪、河北东部和四 川攀枝花一西昌地区有分布。与矿区查明资源储量相似, 铁矿产能富集区同样主要分布 在胡焕庸线东南部，西北地区仅新疆有三个三级核，分布在阿勒泰、天山和西昆仑地区。

\section{2 铁矿资源开发条件评价}

\section{2 .1 缺水程度评价}

中国缺水程度的空间布局大致呈现南方轻、北方重，沿海沿江轻、内陆重的特征 (图 4)。具体来看，长江中下游地区、华南地区、青海北部、陕西、新疆南部、大兴安 
岭地区以及除云南以外的西南地区 属于基本不缺水或轻微缺水区; 西 藏西部和北部、甘肃中部和南部大 部分为中度缺水区; 内蒙古锡林郭 勒、黄河内蒙古段与山西段周缘属 于较严重缺水区; 而新疆塔城、吐 鲁番、哈密以及河北河南中部、安 徽北部、胶东半岛等地区属于严重 缺水区。

\subsection{2 交通优势度评价}

中国交通优势度大致呈现东南 部较高、西北部较低, 大城市较 高、小城镇和乡村较低的格局 （图 5)。高水平地区主要集中在沿 海、沿江港口以及中部省会城市周 边, 交通干线和路网相对密集; 中 高水平地区主要集中东南半壁和西 南部省会城市周边, 各类交通干线 等级、密度处于中等水平; 中低水 平地区主要集中在西北部省会城 市、河西走廊、青海东部、内蒙 古、滇西以黑龙江东北部等地区, 道路网密度相对稀疏; 低水平地区 主要分布在西北部, 路网极其稀 疏，可达性非常低。

\section{3 铁矿资源市场需求评价}

图6 为中国黑色金属冶炼及压延 加工企业分布图。可以看出, 中国 黑色金属治炼与压延加工企业主要

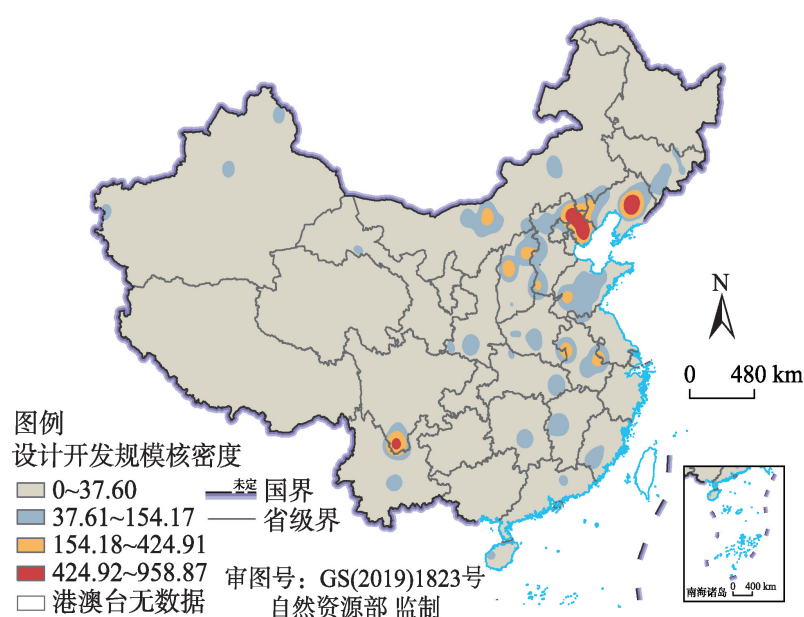

图 3 中国铁矿采矿权设计开采规模核密度

Fig. 3 Kernel density distribution of design mining scales of iron ore mining rights

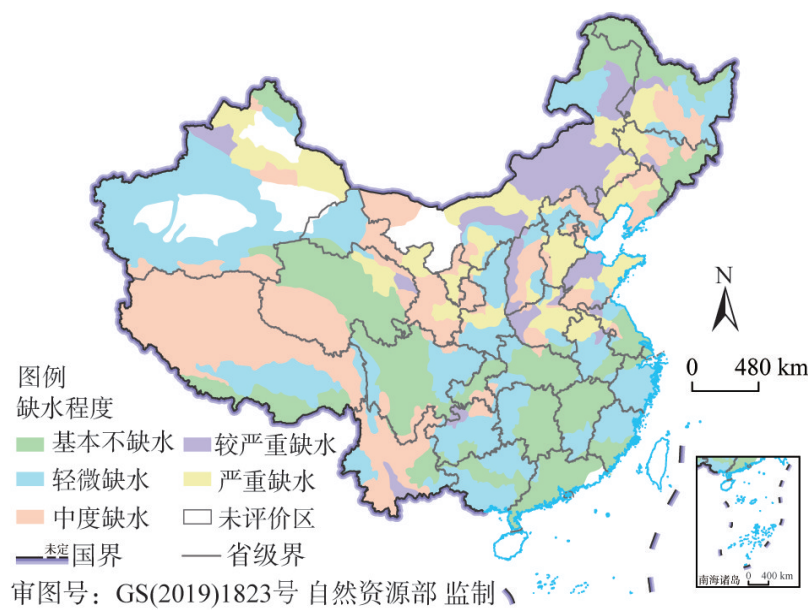

图 4 中国缺水程度分区

Fig. 4 Distribution of water shortage degree areas in China 分布在东南部地区，由沿海向内陆数量急剧减少，京津冀和长三角地区密度最高。从省 级行政区来看，江苏数量最多，超过了 5000 个；其次为河北和山东，超过了 3000 个; 浙江、天津和辽宁数量超过了 2000 个, 山西和广东超过了 1000 个, 安徽、四川和河南 超过了 900 个，湖北、福建和内蒙古超过了 500 个。此外，新疆有约 250 余个，主要分布 在乌鲁木齐及周边，以及西昆仑地区。从城镇尺度来看，省会城市企业数量整体高于一 般城镇。

\section{4 铁矿资源基地划定结果}

将资源基础三项指标评价结果识别出的铁矿资源潜力富集区、储量富集区和产能富 集区进行合并，初步识别出辽宁鞍山一本溪、冀东、山西忻州一吕梁、鲁中一鲁西、内 蒙古包头、安徽霍邱、宁芜庐枞、鄂西南、四川攀枝花一西昌以及云南澜沧等 10 个铁矿 资源基地。 
与黑色金属冶炼与压延加工企 业空间分布的对比分析来看, 以上 10 个铁矿资源基本能够覆盖中国东 中部以及辽宁、吉林、黑龙江南 部、内蒙古中部地区、宁夏北部、 四川东部与南部、云南、广西、贵 州等地区，而甘肃、新疆等地由于 交通基础设施不便，由上述 10 个铁 矿资源基地进行供给难度较大，成 本偏高, 尤其是新疆。同时, 为贯 彻中国区域协调发展战略, 本文认 为还应在西北地区部署至少一个铁 矿资源基地。由资源基础分析结果 来看, 新疆天山和西昆仑地区已具 备一定铁矿开发基础, 且拥有坎苏 上游、黑尖山、尾亚、赞坎等三级 预测区, 预测资源量也相对较可 观, 考虑到西昆仑与天山地区相距 较远, 且天山地区水资源较缺乏, 能够支撑铁矿资源开采的规模有 限, 因此, 应当在这两个地区分别 设置一个铁矿资源基地。

综合来看认为, 应划定 12 个铁 矿资源基地，包括辽宁鞍山一本溪、 冀东、四川攀枝花一西昌、山西忻州 一吕梁、鲁中一鲁西、内蒙古包头、 安徽霍邱、宁芜庐枞、鄂西南、云南 澜沧、新疆天山和新疆西昆仑等。以 上 12 个铁矿资源基地与《全国矿产 资源规划（2016-2020年）》中提 出的辽宁鞍本、河北冀东、内蒙古

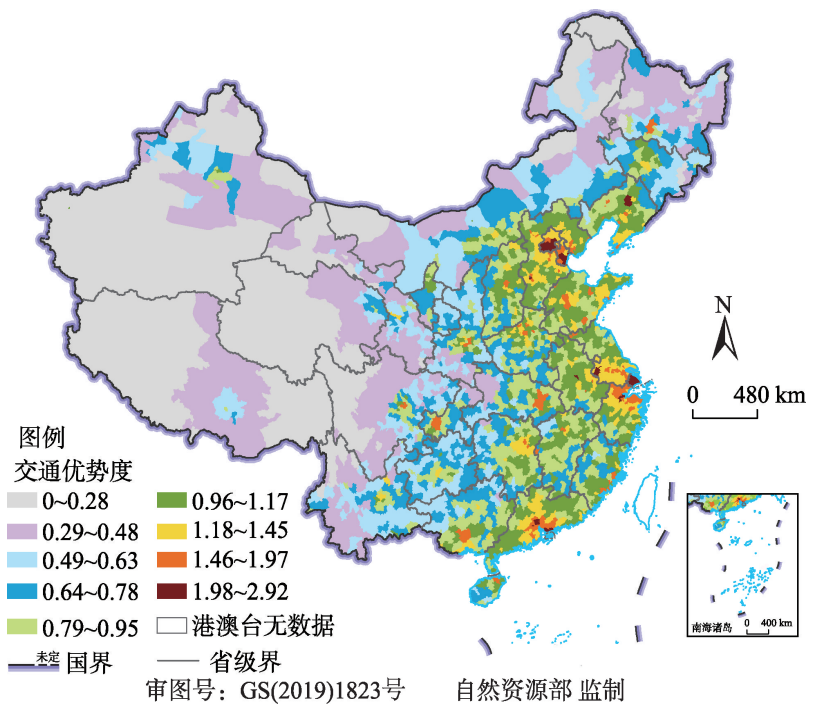

图 5 中国交通优势度分布 ${ }^{[41]}$

Fig. 5 Spatial configuration of transport superiority in China

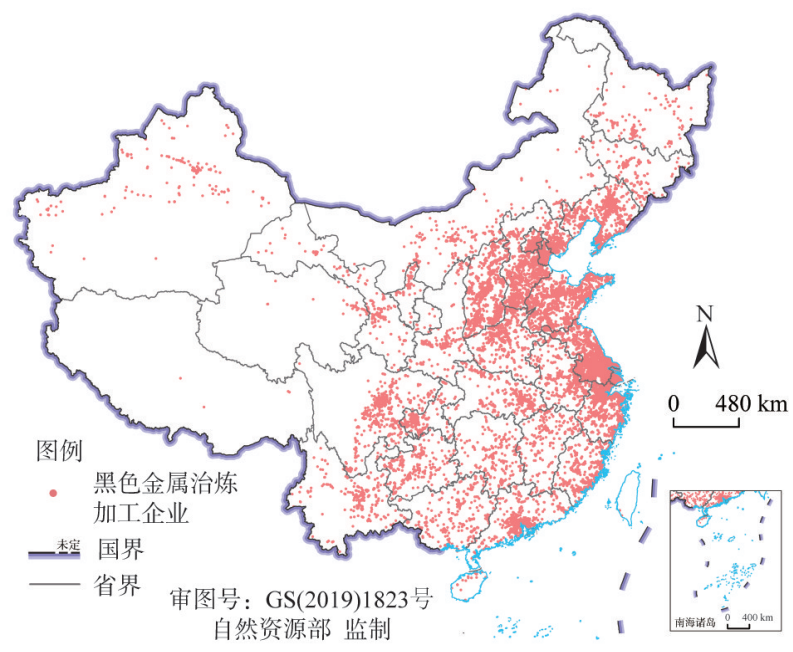

图 6 中国黑色金属冶炼及压延加工企业分布

Fig. 6 Distribution of ferrous metal smelting and rolling enterprises in China 包头、山西忻州一吕梁、山东鲁中一鲁西、新疆天山、新疆西昆仑、四川攀西和宁芜庐枞 等 10 个铁矿资源基地具有高度一致性, 并多出了鄂西南和云南澜沧两个铁矿资源基地, 补充完善了全国铁矿资源基地建设方案。

\section{3 结论}

本文在分析矿产资源基地布局影响因素的基础上，构建了以资源基础、开发条件、 市场需求以及国家战略为准则层, 包含八项具体指标的矿产资源基地划定指标体系, 并 以铁矿为例开展了实证研究, 主要研究结论如下: 
（1）矿产资源基地布局主要受到资源基础、开发条件、生态环境、市场需求以及国 家战略的影响。其中资源基础包括资源潜力、资源储量以及产能等三个方面，开发条件 主要包括基础设施、水资源、能源等支撑矿产资源开发与贸易的要素，市场需求主要表 现为矿产资源的最直接需求对象一冶炼加工企业的需求。此外，作为国家的空间政策区 之一，矿产资源基地建设还应贯彻落实区域协调发展战略。

(2) 无论是铁矿资源储量富集区还是产能富集区，均主要分布在胡焕庸线东南部, 西北地区仅新疆、甘肃和青海海西地区拥有一定规模的储量，新疆阿勒泰、天山和西昆 仑地区目前形成了一定铁矿开发规模。黑色金属冶炼及压延加工企业同样主要分布在东 南部地区，由沿海向内陆数量急剧减少，京津冀和长三角地区密度最高。

（3）综合分析全国预测资源量、矿区查明资源储量、采矿权设计开采规模以及交通 优势度、缺水程度、黑色金属冶炼与压延加工企业分布结果，本文在全国识别了辽宁鞍 山一本溪、冀东、四川攀枝花一西昌、山西忻州一吕梁、鲁中一鲁西、内蒙古包头、安 徽霍邱、宁芜庐枞、鄂西南、云南澜沧、新疆天山、新疆西昆仑等 12 个铁矿资源基地。

与以往关于中国铁矿资源基地的划定结果相比，通过对评价指标体系的完善和改 进，不仅在资源基础评价方面增加了对预测资源量的评价，同时考虑了开发条件、市场 需求和区域协调发展战略等指标，对铁矿资源基地进行了划定，研究结果对基地管理的 参考价值更强。本文构建的矿产资源基地划定指标体系，以及在铁矿资源基地划定实证 研究中所采用的划定方法，对于 “十四五” 时期我国矿产资源基地调整优化具有一定参 考价值，对其他矿产资源空间政策区的划定同样具有借鉴意义。

\section{参考文献(References):}

[1] PAULIUK S, WANG T, MÜLLER D B. Steel all over the world: Estimating in-use stocks of iron for 200 countries. Resources, Conservation and Recycling, 2013, 71: 22-30.

[2] 沈镭, 张红丽, 钟帅, 等. 新时代下中国自然资源安全的战略思考. 自然资源学报, 2018, 33(5): 721-734. [SHEN L, ZHANG H L, ZHONG S, et al. Strategic thinking on the security of natural resources of China in the New Era. Journal of Natural Resources, 2018, 33(5): 721-734.]

[3] 陈其慎, 于汶加, 张艳飞, 等. 资源一产业“雁行式”演进规律. 资源科学, 2015, 37(5): 871-882. [CHEN Q S, YU W J, ZHANG Y F, et al. Resources-industry "flying geese" evolving pattern. Resources Science, 2015, 37(5): 871-882.]

[4] 王安建, 王高尚, 邓祥征, 等. 新时代中国战略性关键矿产资源安全与管理. 中国科学基金, 2019, 33(2): 133-140. [WANG A J, WANG G S, DENG X Z, et al. Security and management of China's critical mineral resources in the New Era. Bulletin of National Natural Science Foundation of China, 2019, 33(2): 133-140.]

[5] DAW G. Security of mineral resources: A new framework for quantitative assessment of criticality. Resources Policy, 2017, 53: 173-189.

[6] 金碚. 关于 “高质量发展”的经济学研究. 中国工业经济, 2018, (4): 5-18. [JIN B. Study on the "high-quality development" economics. China Industrial Economics, 2018, (4): 5-18.]

[7] 曾现来, 间晓宇, 张宇平, 等. 中国资源的进出口与产出率: 演化、挑战及对策. 自然资源学报, 2018, 33(4): 552-562. [ZENG X L, YAN X Y, ZHANG Y P, et al. Importation, exportation, and productivity of resources in China: Evolution, challenges, and solutions. Journal of Natural Resources, 2018, 33(4): 552-562.]

[8] 习近平. 决胜全面建成小康社会夺取新时代中国特色社会主义伟大胜利: 在中国共产党第十九次全国代表大会上 的报告. 北京: 人民出版社, 2017. [XI J P. Determine the Victory in Building a Well-off Society in an all-round Way and Achieve Great Victory of Socialism with Chinese Characteristics in the New Era: The Report at the 19th National Congress of the Communist Party of China. Beijing: People's Publishing House, 2017.]

[9] 吴尚昆, 张玉韩. 中国矿产资源基地分布与管理政策研究. 中国工程科学, 2019, 21(1): 81-87. [WU S K, ZHANG Y 
H. Distribution and management policy of energy resource bases in China. Strategic Study of CAE, 2019, 21(1): 81-87.]

[10] 王梓懿, 张京祥, 李镝. 空间政策分区的国际经验及其对主体功能区战略完善的启示., http: //kns.cnki.net/kcms/detail/11.5583.TU.20200423.1700.002.html, 2020-04-23. [WANG Z Y, ZHANG J X, LI D. International experience of spatial policy zoning and its enlightenment to the planning and improvement of main functional areas, http: //kns.cnki. net/kcms/detail/11.5583.TU.20200423.1700.002.html, 2020-04-23.]

[11] SHAFER C. US national park buffer zones: Historical, scientific, social, and legal aspects. Environmental Management, 1999, 23(1): 49-73.

[12] SHELFORD V. List of reserves that may serve as nature sanctuaries of national and international importance, in Canada, the United States, and Mexico. Ecology, 1941, 22(1): 100-107.

[13] KNIGHT A, COWLING R, ROUGET M, et al. Knowing but not doing: Selecting priority conservation areas and the research-implementation gap. Conservation Biology, 2008, 22(3): 610-617.

[14] MYERS N, MITTERMEIER R, MITTERMEIER C, et al. Biodiversity hotspots for conservation priorities. Nature, 2000, 403: 853-858.

[15] BLASI C, MARIGNANI M, COPIZ R, et al. Important plant areas in Italy: From data to mapping. Biological Conservation, 2011, 44(1): 220-226.

[16] KOYAMA Y. What is the so-called national comprehensive development plan (part one). Land Comprehensive Research, 2011, Spring: 18-32.

[17] BLOTEVOGEL H H. Neuorientierung der Raumordnungspolitik? Die neuen, Leitbilder und andlungsstrategien fiir die Raumentwicklung in Deutschland" in der Diskussion. Raumforschung und Raumordnung, 2006, 64(6): 460- 472. [BLOTEVOGEL H H. A re-orientation of spatial planning policy? The new "Concepts and Action Strategies for Spatial Development in Germany" under discussion. Space Research and Spatial Planning, 2006, 64(6): 460-472.]

[18] SCOTT M, DIMITRAKOPOULOS R. Quantitative analysis of mineral resources for strategic planning: Implications for Australian geological surveys. Natural Resources Research, 2001, 10(3): 159-177.

[19] WAGNER H, TIESS G, ŠOLAR S, et al. Minerals planning policies in Europe. Materials and Geoenvironment, 2006,52 (3): 607-620.

[20] MAKAROV A. Science and technology forecasts and problems of Russia's energy development up to 2030. Herald of the Russian Academy of Sciences, 2009, 79(2): 99-108.

[21] WRIGHTON C E, BEE E J, MANKELOW J M. The development and implementation of mineral safeguarding policies at national and local levels in the United Kingdom. Resources Policy, 2014, 41: 160-170.

[22] NEWSHAM R, HOUGH E, MORIGI A N. Minerals safeguarding areas for Shropshire and Telford \& Wrekin. http://nora.nerc.ac.uk/id/eprint/20028, 2012-10-17.

[23] DUNN J R, CUEMAN E R, PRESTON C M. Zoning for mineral in Carroll county, Maryland. In: Proceedings of the Fourteenth Annual Forum on the Geology of Industrial Minerals. New York: State Mus. Bull., 1980: 3-5.

[24] BAKER D, HENDY B. Planning for Sustainable Construction Aggregate Resource in Australia. In: Sidwell, Anthony Charles (Ed.), Proceedings of the Queensland University of Technology Research Week International Conference. Queensland: Queensland University of Technology, Brisbane., 2005: 4-5.

[25] AMIRI H, SAMADIAN F, YAHOO M, et al. Natural resource abundance, institutional quality and manufacturing development: evidence from resource-rich countries. Resources Policy, 2019, 62: 550-560.

[26] 吴钢, 魏东, 周政达, 等. 我国大型煤炭基地建设的生态恢复技术研究综述. 生态学报, 2014, 34(11): 2812-2820. [WU G, WEI D, ZHOU Z D, et al. A summary of study on ecological restoration technology of large coal bases construction in China. Acta Ecologica Sinica, 2014, 34(11): 2812-2820.]

[27] 范继涛, 贾文龙, 薛亚洲. 浅析矿产资源储备基地选择的影响因素. 中国矿业, 2010, 19(8): 12-14. [FAN J T, JIA W L, XUE Y Z. Analysis on factors of mineral resources reserve base selection. China Mining Magazine, 2010, 19(8): 1214.]

[28] 陈万勇, 侯奎. 试论攀钢基地的矿产资源体系. 自然资源学报, 1990, 5(1): 31-41. [CHEN W Y, HOU K. On the mineral resource system of the Panzhihua Iron and Steel Base. Journal of Natural Resources, 1990, 5(1): 31-41.]

[29] 李德亭, 刘建明, 袁怀雨. 关于建立大兴安岭固体矿产资源基地的探讨. 中国矿业, 2004, 13(7): 3-6. [LI D T, LIU J 
M, YUAN H Y. Discussing in founding solid mineral resource base of Daxinganling Region. China Mining Magazine, 2004, 13(7): 3-6.]

[30] 肖克炎, 娄德波, 阴江宁, 等. 中国铁矿资源潜力定量分析. 地质通报, 2011, 30(5): 650-660. [XIAO K Y, LOU D B, YIN J N, et al. Quantified research on iron potential of China. Geological Bulletin of China, 2011, 30(5): 650-660.]

[31] 梁仁彩. 试论能源基地的类型及其综合发展. 地理研究, 1985, 4(2): 9-17. [LIANG R C. Dealing with the division of the patterns of energy basis and its comprehensive development. Geographical Research, 1985, 4(2): 9-17.]

[32] 罗德江, 程龙, 刘红军, 等. 四川省矿产资源勘查开发基地划分与评价. 四川地质学报, 2016, 36(4): 689-693. [LUO D J, CHENG L, LIU H J, et al. Partitioning and evaluation of mineral exploration and exploitation bases in Sichuan province. Acta Geologica Sichuan, 2016, 36(4): 689-693.]

[33] 马吉宇. 基于聚类分析的我国铁矿资源勘查开发基地划分研究. 北京: 中国地质大学(北京), 2015. [MA J Y. Study on division of China iron ore exploration and development base using cluster analysis. Beijing: China University of Geosciences (Beijing), 2015.]

[34] 张玉韩, 董延涛, 马吉宇. 基于核密度估计的我国铁矿资源开发基地研究. 中国矿业, 2015, 24(11): 46-50. [ZHANG Y H, DONG Y T, MA J Y. Research on exploitation base of iron mine resources in China using nuclear density estimation. China Mining Magazine, 2015, 24(11): 46-50.]

[35] 王春艳, 牛丽贤. 基于 GIS 的有色金属勘查开发基地区划方法研究. 矿产勘查, 2016, 7(1): 191-197. [WANG C Y, NIU L X. Study on GIS-based regionalization methods for non-ferrous metal resources exploration and exploitation bases. Mineral Exploration, 2016, 7(1): 191-197.]

[36] 龙如银, 杨家慧. 国家矿产资源安全研究现状及展望. 资源科学, 2018, 40(3): 465-476. [LONG R Y, YANG J H. Research status and prospect of national mineral resource security. Resources Science, 2018, 40(3): 465-476.]

[37] 张玉韩, 侯华丽, 沈悦, 等. 乌蒙山片区矿产资源开发功能分区及扶贫政策探索. 资源科学, 2018, 40(9): 1716-1729. [ZHANG Y H, HOU H L, SHEN Y, et al. Study on the functional division of mineral resources development and poverty alleviation policy in Wumeng Mountain Area. Resources Science, 2018, 40(9): 1716-1729.]

[38] 间军印, 赵国杰. 区域矿产资源开发生态经济系统及其模拟分析. 自然资源学报, 2009, 24(8): 1334-1342. [YAN J Y, ZHAO G J. Simulating on ecological \& economic system of regional mineral resources exploitation. Journal of Natural Resources, 2009, 24(8): 1334-1342.]

[39] 侯华丽, 张玉韩, 吴尚昆, 等. 基于多要素的中国固体矿产资源丰度评价. 中国人口·资源与环境, 2016, 26(s2): 240244. [HOU H L, ZHANG Y H, WU S K, et al. Solid mineral resources abundance evaluation in China based on multiple elements. China Population, Resources and Environment, 2016, 26(s2): 240-244.]

[40] 王爱虎, 钟雨晨. 中国吸引跨国外包的经济环境和政策研究. 经济研究, 2006, (8): 81-92. [WANG A H, ZHONG Y C. Research on the economic environment and policies of China in attracting international outsourcing. Economic Research Journal, 2006, (8): 81-92.]

[41] 金凤君, 王成金, 李秀伟. 中国区域交通优势的甄别方法及应用分析. 地理学报, 2008, 63(8): 787-798. [JIN F J, WANG C J, LI X W. Discrimination method and its application analysis of regional transport superiority. Acta Geographica Sinica, 2008, 63(8): 787-798.]

[42] ROSENBLATT M. Remarks on some nonparametric estimates of a density function. The Annals of Mathematical Statistics, 1956, 3: 832-837.

[43] PARZEN E. On estimation of a probability density function and mode. Annals of Mathematical Statistics, 1962, 33(3): 1065-1076.

[44] 金巍, 刘双双, 张可, 等. 农业生产效率对农业用水量的影响. 自然资源学报, 2018, 33(8): 1326-1339. [JIN W, LIU S $\mathrm{S}$, ZHANG K, et al. Influence of agricultural production efficiency on agricultural water consumption. Journal of Natural Resources, 2018, 33(8): 1326-1339.]

[45] SILVERMAN B. Density estimation for statistics and data analysis. Chapman \& Hall/CRC, 1986.

[46] 周璞,侯华丽, 吴尚昆. 我国矿产资源自然区划研究. 中国矿业, 2019, 28(2): 29-33. [ZHOU P, HOU H L, WU S K. Preliminary study on natural zoning of mineral resources in China. China Mining Magazine, 2019, 28(2): 29-33.]

[47] 阴江宁, 肖克炎, 娄德波. 中国铁矿预测模型与资源潜力分析. 地学前缘, 2018, 25(3): 107-117. [YIN J N, XIAO K Y, LOU D B. Prediction model and resource potential of iron in China. Earth Science Frontiers, 2018, 25(3): 107-117.] 
[48] 雷岩, 刘伯恩. 构建国外矿产资源稳定供应机制的思考. 中国国土资源经济, 2014, 27(6): 51-55. [LEI Y, LIU B E. Establishing a steady supply mechanism of foreign mineral resources. Natural Resource Economics of China, 2014, 27(6): 51-55.]

[49] 侯华丽, 吴尚昆, 王传君, 等. 基于基尼系数的中国重要矿产资源分布不均衡性分析. 资源科学, 2015, 37(5): 915920. [HOU H L, WU S K, WANG C J, et al. Uneven spatial distribution analysis of important Chinese mineral resources based on Gini coefficients. Resources Science, 2015, 37(5): 915-920.]

[50] 王嫱. 2018 年全球铁矿资源供需形势分析. 中国国土资源经济, 2020, 33(3): 59-68. [WANG Q. Analysis of global supply and demand situation of iron ore resources in 2018. Natural Resource Economics of China, 2020, 33(3): 59-68.]

\title{
The formulation and application of the index system for the delimitation of mineral resources bases in China: A case study of iron ore
}

\author{
ZHANG Yu-han ${ }^{1,2}$, WU Shang-kun ${ }^{2}$, ZHANG Shou-ting ${ }^{1}$, WANG Cheng-fu' ${ }^{1}$, ZHAO Yu ${ }^{1}$ \\ (1. School of Earth Sciences and Resources, China University of Geosciences, Beijing 100083, China; \\ 2. Chinese Academy of Natural Resources Economics, Beijing 101149, China)
}

\begin{abstract}
Mineral resources bases are the strategic core area to optimize the layout of mineral resources exploration and development in China and ensure resources security. Based on the analysis of the influencing factors of mineral resources bases layout, this study formulated an index system to delimitate the mineral resources bases from the following four aspects: resource endowment, development conditions, market demand and national strategy. The resource endowment includes three indexes, namely, forecast resources, identified resources and development \& utilization status quo; the development conditions include water shortage degree and transportation superiority; the market demand includes both the layout and output values of subsequent smelting and processing enterprises; the national strategy can be mainly reflected by the requirements of regional coordinated development strategy for the layout of mineral resources bases. On this basis, taking iron ore as an example, this paper carried out an empirical study on the delimitation of mineral resources bases to test the rationality of the index system. After evaluation of the resource endowment indexes by cluster analysis and kernel density estimation, and analysis of all the other indexes, twelve iron ore resources bases were identified through comprehensive judgment, including Anshan- Benxi of Liaoning, Eastern Hebei, Panzhihua-Xichang of Sichuan, Xinzhou-Luliang of Shanxi, Central-Western Shandong, Baotou of Inner Mongolia, Huoqiu and Ningwu-Luzong of Anhui, Southwest Hubei, Lancang of Yunnan, Tianshan and Western Kunlun of Xinjiang. The results provide some references for the adjustment and optimization of China's mineral resources bases for the "14th Five-year Plan", and might be significative to the delimitation of other mineral resources spatial policy areas.
\end{abstract}

Keywords: mineral resources bases; index system; iron ore; kernel density estimation 